\title{
Some Responses of Riparian Soils to Grazing Manage- ment in Northeastern Oregon
}

\author{
C.C. BOHN AND J.C. BUCKHOUSE
}

\begin{abstract}
Infiltration, sediment production, penetrometer penetrability and bulk density were measured on control/treatment paired plots of several grazing schemes in a riparian zone of northeastern Oregon. Treatments were in effect over a period of 5 years. Restrotation favored the hydrologic parameters measured, while deferred rotation and season-long did little to enhance, and sometimes hindered, hydrologic expression. Late-season grazing in September demonstrated a positive hydrologic response, whereas lateseason grazing in October was negative-probably due to the onset of fall rains and a change in soil moisture conditions.
\end{abstract}

Although land managers generally acknowledge that the rate at which an upland soil accepts water largely determines erosion rates, surface ponding, soil moisture, and ground water recharge, little attention has focused on infiltration in riparian areas. Infiltration into the soil may influence stream systems because erosion delivers sediment and nutrients to the stream, and discharge and dissolved salt concentrations respond differently to runoff and groundwater flows (Morisawa 1968). Infiltration, therefore, may be of particular interest in a riparian zone, which is the last terrestrial area water crosses before entering the stream. Furthermore, compaction and low infiltration rates may interfere with the riparian zone's function as a stream source area. These areas contribute to streamflow according to rainfall characteristics and the water storage and transmission properties of the soil (Branson et al. 1981).

Several studies have linked cattle grazing with changes in upland soil properties (Gifford and Hawkins 1978, Moore et al. 1979. Branson et al. 1981, Gifford 1981). Livestock on upland systems can increase soil compaction and depress infiltration by grazing protective plant cover, reducing soil organic matter, and trampling the soil surface. The physical disturbance and removal of protective vegetation by grazing animals may dislodge soil particles, thereby increasing the potential for sediment production. Although there is little documentation of the effects of cattle grazing on soil properties in a riparian zone, the close linkage between grazing, soil-water relations, and plant communities on the uplands suggests that a similar pattern in the stream bottoms may exist. In fact, the moist riparian soils may be particularly subject to compaction and its attendant impacts on water transmission and root growth and aeration. Moist soils are generally more vulnerable to compaction and riparian areas tend to be moist more often and for longer periods than upland soils because (1) water is directed downslope to the riparian zone, (2) water does not run off flat floodplains and meadows as readily as off slopes, and (3) the water table is high in riparian areas. Increased sediment production from animal disturbance is also a concern in the riparian zone, where there is little or no opportunity for dislodged soil particles to settle before reaching the stream. In many areas, however, livestock production currently

\footnotetext{
At the time of the research, the authors were graduate research assistant and associate professor, Department of Rangeland Resources, Oregon State University, Corvallis. Bohn is currently a watershed technician for the U.S. Forest Service. Range Evaluation Project.

The funding for this research was provided by the Pacific Northwest Forest and Range Experiment Station, Range and Wildlife Habitat Laboratory, La Grande, Oregon. Special thanks are due to Dr. Jack Ward Thomas and Mr. Larry Bryant for the cooperation they extended throughout the entire study.

This article is submitted as Technical Paper No. 7272

Manuscript accepted January 10, 1985
}

depends on access to streams for drinking water, and the reduction or exclusion of livestock is economically undesirable. Consequently manipulation of soil condition through the use of a particular grazing system may be an attractive option.

In 1975, the U.S. Forest Service, Pacific Northwest Forest and Range Experiment Station initiated a multidisciplinary case study at Meadow Creek on the Starkey Experimental Forest and Range in northeastern Oregon. The study was conducted through the Range and Wildlife Habitat Laboratory in La Grande, Ore., and spanned 7 years. One objective was to compare infiltration rates, sediment production, and compaction associated with different systems of grazing cattle in a historically deteriorated riparian zone.

\section{Site Description}

The Starkey Experimental Forest and Range is located in the Blue Mountains about $48 \mathrm{~km}$ southwest of La Grande, Ore. The study area includes approximately $8 \mathrm{~km}$ of strea $\mathrm{m}$ coursing in open ponderosa pine-Douglas fir forest. The floodplain rises about 1 meter above mean water level at low flow and a verages 23 meters wide. Soil data is sketchy, but preliminary soil maps on file at the Range and Wildlife Habitat Laboratory in La Grande generally describe interspersed patches of well-drained Veezie gravelly loam (coarse-loamy over sandy or sandy-skeletal, mixed mesic cumulic haploxerolls) and Voats sandy loam (sandy-skeletal, mixed mesic fluventic haploxerolls). Areas of unvegetated riverwash also exist, as well as an occasional boggy patch. Average annual precipitation is $50 \mathrm{~cm}$, occurring primarily as winter snowfall, with some contribution from spring and fall rain.

In the first part of this century, the study area was subjected to logging operations, which included roads and a splash dam, and to heavy livestock grazing. The Forest Service dedicated the Starkey Forest for research purposes in 1940 and began to regulate the land use activities and reduce grazing pressure (Skovlin et al. 1976). Although vegetation in the pastures gradually improved, the stream bottoms continued to be heavily used as cattle concentrated there for water and succulent forage (Strickler per. comm. 1980). Rocky Mountain elk (Cervus elaphus nelsoni) use the Forest primarily for spring and fall range, and mule deer (Odocoileus hemionus hemionus) are present year-round.

\section{Methods}

\section{Stocking Systems}

The area immediately adjacent to Meadow Creek was fenced into several small, contiguous pastures (Fig. 1) and stocked June through October with yearling heifers at the moderate rate used on the Starkey Forest as a whole ( 3.2 ha/ AUM). These pastures held 2 to 20 heifers, depending on the pasture size and grazing system (Table 1). Because of the small pasture size, the number of animals using the riparian area was less than occurred on large pastures stocked at similar rates.

The following management options were applied to the Meadow Creek pastures: four-pasture rest-rotation, deferred rotation, season-long grazing, and no grazing. Rest-rotation pastures followed a pattern of rest, grazing late June-mid-August, grazing season-long, grazing mid-August-mid-October. Deferred rotation pastures were grazed alternate years, late June-mid-August and 


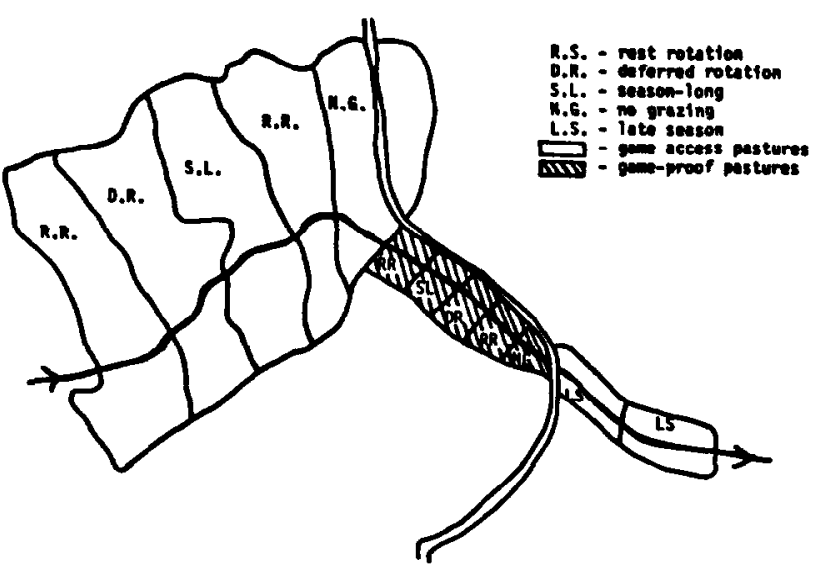

Fig. 1. Diagram of Pastures on Meadow Creek.

mid-August-mid-Octobcr. Season-long grazing lasted from late June-mid-October. Big game were allowed access to all treatments in one area and excluded from the same treatments in another area. In addition, short-duration, high-intensity, deferred-rotation grazing was tested in September and October. All pastures contained a small control exclosure.

\section{Sampling Infiltration}

Infiltration rates were estimated with a Rocky Mountain infiltrometer (Dortignac 1951) and a ring infiltrometer (Haise et al. 1956, Bertrand 1965) on paired treatment-exclosure plots in each grazing system. All plots were moistened and allowed to drain prior to testing to alleviate differences due to antecedent moisture. Ocular estimates of vegetative cover were recorded for interpretive use. The Rocky Mountain infiltrometer plots received 28-minute applications of simulated rainfall at a rate of approximately 7 $\mathrm{cm} /$ hour. This was the lowest application rate of the machine, simulating severe storm conditions for the area. Three $76.2 \times 30.5$ $\mathrm{cm}$ subplots were sampled at every plot early in the grazing season each year. The average infiltration rate from 5 -minute intervals for times 3-28 minutes and the final rate on all treatments were calculated and used in separate analysis of variance (ANOVA) and least significant difference (LSD) tests. Tests were made in 1975, 1976, 1980 , and 1981. In calibration years (1975 and 1981) the pastures were not stocked with cattle. Potential sediment production was measured from runoff produced on the Rocky Mountain infiltrometer plots.
Fifteen-centimeter diameter cylinders were used as single ring infiltrometers in early summer 1980 , late summer 1980 , and early summer 1981 . Some pastures were too stony to properly set the rings and were dismissed as unsuitable. Pastures where soils were suitable were tested in exclosure-treatment pairs. Mean and final infiltration rates were calculated from the time needed to drain 10 $\mathrm{cm}$ of water and used in separate ANOVA and LSD tests. Rate measurements were attempted at 9 subplots for each plot in each season, but the actual sample size varied somewhat due to problems with rocks and animal burrows. The numerical estimates from both types of infiltrometers were useful for establishing trends, but should not be considered absolute values.

\section{Sampling Soil Density and Bulk Density}

Soil bulk density and penetrability were also estimated concurrently at the ring infiltrometer plots (Blake 1965, A.S.A.E. 1975). Eighteen measurements, to a depth of about $3 \mathrm{~cm}$, were collected from each plot with a proving ring penetrometer in early summer 1980 , late summer 1980 , and early summer 1981 . Three gravimetric soil cores per plot were collected through the duff layer into the upper $3.8 \mathrm{~cm}$ of soil in early summer 1981 and analyzed for bulk density. Differences between treatments and their paired exclosures were tested by one-way ANOVA and LSD.

\section{Statistical Analysis}

The Meadow Creek Study was designed as a case study and, as such, was not replicated. Statistical analysis was performed on multiple samples within a treatment as a guide in interpreting trends and processes specific to the conditions on Meadow Creek. The infiltration analysis examined patterns between treatmentexclosure pairs rather than comparing absolute values. Data of this nature are usually analyzed one of two ways-either for changes over time at a particular site or for differences between a treated area and a control. Neither of these approaches was entirely appropriate for these data because analysis for changes over time did not account for environmental influences other than the treatment, and treatment-control comparisons were only valid when both plots had equal value for the parameters at the first measurement. This is a difficult restriction in riparian areas where soil types and conditions often occur in extremely small, irregular patches due to channel changes and other hydrologic occurrences. Large sample sizes may be required and paired plots may not always have the same absolute values on test parameters. Therefore, an analysis was devised which employed part of each technique to examine trends rather than absolute values. First, each plot was analyzed

Table 1. Meadow creek stocking schedule.

\begin{tabular}{|c|c|c|c|c|c|}
\hline Grazing treatment & $\begin{array}{l}\text { Approx. pasture } \\
\text { size (ha) }\end{array}$ & $\begin{array}{l}\text { No. of } \\
\text { animals }\end{array}$ & $\begin{array}{l}\text { Stocking } \\
\text { rate }\end{array}$ & $\begin{array}{l}\text { Approx. stream } \\
\text { frontage }\end{array}$ & $\begin{array}{c}\text { Meters of } \\
\text { stream/animal/season }\end{array}$ \\
\hline \multicolumn{6}{|l|}{ Big Game Access } \\
\hline rest rotation & 73.8 & 20 or 0 & $3.2 \mathrm{ha} / \mathrm{AUM}$ & 544 & 27 \\
\hline deferred rota. & 82.0 & 20 & $3.2 \mathrm{ha} / \mathrm{AUM}$ & 444 & 22 \\
\hline season-long (5) & 56.6 & 10 & $3.2 \mathrm{ha} / \mathrm{AUM}$ & 409 & 41 \\
\hline rest rotation & 61.2 & 0 or 20 & $3.2 \mathrm{ha} / \mathrm{AUM}$ & 538 & 27 \\
\hline no grazing & 49.0 & 0 & - & 352 & - \\
\hline \multicolumn{6}{|l|}{ Big Game-Proof } \\
\hline rest rotation & 5.7 & 4 or 0 & $3.2 \mathrm{ha} / \mathrm{AUM}$ & 238 & 60 \\
\hline season-long (5) & 4.7 & 2 & $3.2 \mathrm{ha} / \mathrm{AUM}$ & 206 & 103 \\
\hline deferred rota. & 4.7 & 4 & $3.2 \mathrm{ha} / \mathrm{AUM}$ & 174 & 44 \\
\hline rest rotation & 4.1 & 0 or 4 & $3.2 \mathrm{ha} / \mathrm{AUM}$ & 257 & 64 \\
\hline no grazing & 4.0 & 0 & - & 248 & - \\
\hline \multicolumn{6}{|l|}{ Late Season } \\
\hline September & 6.2 & 12 & $.85 \mathrm{ha} / \mathrm{AUM}$ & 648 & 54 \\
\hline October & 5.7 & 12 & $.77 \mathrm{ha} / \mathrm{AUM}$ & 397 & 33 \\
\hline
\end{tabular}

IStocking rate to achieve $70 \%$ utilization. 
for statistically significant change over time. Then, significant changes for each treatment plot were graphically compared with the response on its paired exclosure plot to, in effect, remove any environmental influences which would have affected both plots equally. Treatment response was indicated when significant changes on the treatment differed from those found on the paired exclosure. Several treatment-exclosure combinations were possible and each combination was coded as "plus", "minus" or "zero" based on the treatment's response to its paired exclosure (Table 2).

Table 2. Treatment response code for trends index in soil infiltration.

\begin{tabular}{ccc}
\hline \hline Exclosure plot & Treatment plot & Trend index \\
\hline 1 & 1 & + \\
1 & no change & - \\
1 & 1 & - \\
no change & no change & + \\
no change & 1 & - \\
no change & 1 & 0 \\
1 & 1 & + \\
1 & no change & + \\
\hline
\end{tabular}

$t=$ infiltration rate increase over time (1975 vs. 1981)

$\downarrow=$ infiltration rate decrease over time (1975 vs. 1981)

$+=$ positive trend (increased infiltration rate) attributable to treatment

= negative trend (decreased infiltration rate) attributable to treatment

$0=$ no change in trend attributable to treatment

When long-term data were not available (ring infiltration, bulk density, and penetrability), treatment-exclosure pairs were assumed to be comparable and tested directly with the $t$-test, ANOVA and LSD statistical tests. These results were also coded (Table 3 ).

\section{Results}

Long-term effects on infiltration were estimated from comparison of the Rocky Mountain infiltrometer infiltration rates at 28 minutes in 1975 and 1981. Infiltration increased in several control exclosures, suggesting a process of recovery from the previous heavy grazing. Rest-rotation grazing and no grazing appeared to follow the same patterns found in their paired control exclosures, while deferred rotation and season-long grazing responded negatively relative to their paired control exclosures, regardless of big game accessability. Rocky Mountain infiltrometer data indicated that the September late-season grazing treatment responded similarly to its paired control; however, the October late-season graz-
Table 3. Treatment response code for ring infiltration, soil penetrability and bulk density trend indices.

\begin{tabular}{lcc}
\hline \hline Soil attribute & Net response & Coded trend index \\
\hline Ring infiltration & increase & + \\
decrease & no difference & - \\
increase & 0 \\
denetrability & no difference & + \\
Bulk density & increase & - \\
& decrease & 0 \\
& no difference & + \\
\hline
\end{tabular}

ing treatment had lower infiltration rates than did its control (Table 4).

Sediment production, as estimated from "Sprinkler" runoff, followed the same pattern as infiltration; the response of restrotation and no grazing treatments corresponded to their paired exclosures, while season-long grazing on the game-proof pasture had a negative response relative to its paired exclosure (Table 4).

If conditions are assumed to have been similar within each treatment exclosure pair in 1975, then changes over time can be cstimated by comparing 1975 to 1981 treatment-exclosure ring infiltrometer results. Although these comparisons are not as well defined as the "sprinkler" results, they suggested that rest-rotation plots in the game-proof exclosures demonstrated a positive response relative to their paired controls; whereas the rest-rotation plots in the game-acccss plots were neutral. Season-long grazing plots were negative compared to their controls, in either case. Deferred rotation was negative in the big game access plots, but neutral in the game-proof pastures. Late-season grazing in October produced a negative ring infiltration response although September grazing had no effect.

Because soil compaction tests were not initiated until 1980 , long-term changes were estimated by comparing conditions on treatment-exclosure pairs in 1981. This approach assumed that conditions in each half of a pair were equivalent at the onset in 1975. Compaction, as indexed by a proving ring penetrometer, increased significantly on all tested treatments with big game access. Where big game were excluded, the rest-rotation, deferred rotation, season-long and no grazing treatments did not compact

Table 4. Effects of grazing management on soil properties, a summary of the trend indices, 1975 to 1981 (0.05 significance)'

\begin{tabular}{|c|c|c|c|c|c|}
\hline Grazing treatment & $\begin{array}{l}\text { Rocky Mt. } \\
\text { infiltrometer }\end{array}$ & $\begin{array}{l}\text { Sediment }^{2} \\
\text { production }\end{array}$ & $\begin{array}{c}\text { Ring } \\
\text { infiltrometer }\end{array}$ & $\begin{array}{l}\text { Penetrability } \\
\text { penetrometer }\end{array}$ & $\begin{array}{l}\text { Bulk density } \\
\text { (soil cores) }\end{array}$ \\
\hline \multicolumn{6}{|l|}{ Game access } \\
\hline rest rotation & + & no data & 0 & $\ldots$ & - \\
\hline deferred rotation & - & no data & - & - & 0 \\
\hline season-long ( 5 yrs) & $\ldots$ & no data & - & - & 0 \\
\hline rest rotation & 0 & 0 & no data & no data & no data \\
\hline no grazing & + & + & 0 & - & 0 \\
\hline \multicolumn{6}{|l|}{ Game-proof } \\
\hline rest rotation & + & no data & + & 0 & 0 \\
\hline season-long ( 5 yrs) & - & - & - & -4 & - \\
\hline deferred rotation & - & no data & 0 & 0 & 0 \\
\hline rest rotation & 0 & no data & no data & no data & no data \\
\hline no grazing & + & no data & no data & 0 & no data \\
\hline \multicolumn{6}{|l|}{ Late season } \\
\hline September & + & no data & 0 & 0 & 0 \\
\hline October & - & no data & - & - & 0 \\
\hline
\end{tabular}

'See Tables 2 and 3 for further explanation of response symbols.

2Treatment response trend, relative to exclosure.

3Compares treatment to exclosure statistically.

4 Plot located on trail. 
significantly (Table 4). However, comparisons between big game pastures and game-proof pastures may not be valid in this study since the big game pastures extended onto the uplands and were larger than those which excluded game, and therefore required approximately 5 times more livestock than the smaller pastures to maintain the prescribed stocking rate. Stream frontage remained approximately constant for all pastures so animal impact per unit of streamside area may have been greater on big game pastures. The data may, therefore, reflect greater livestock use of the riparian area rather than big game use. Late-season grazing in October has a negative trend, but late-season grazing in September was neutral.

Bulk density increased significantly only on 1 of the 2 restrotation pastures which allowed big game access and on the season-long grazing which excluded big game. No other grazing systems affected bulk density.

\section{Summary}

Infiltration rates improved in several of the exclosures between 1975 and 1981 , implying that a process of recovery from historical abuses was occurring. Few examples of pristine riparian areas like the one studied here exist for comparison, so "recovery" here may be defined for management purposes as an increase in infiltration rate and decrease in compaction and sediment production. The process of recovery has been recognized in other studies and is usually linked with a period of rest (Gifford and Hawkins 1978, Moore et al. 1979, Branson et al. 1981, Gifford 1981).

Rest-rotation appeared to favor recovery, while deferred rotation and season-long grazing did little to enhance it and sometimes actually seemed to hinder it. The positive infiltration response to the short-duration, high-intensity deferred rotation grazing scheme in September and the negative response to the same application in October probably reflected altered soil conditions in October due to the onset of fall rains.

\section{Literature Cited}

American Society of Agricultural Engineers. 1975. Soil cone penetrometer. Agr. Eng. Yearbook: 368-369.

Bertrand, Anson R. 1965. Rate of water intake in the field. p. 197-209. In: Methods of Soil Analysis, Part I. C.A. Black, ed. Amer. Soc. Agron., Inc. Madison, Wis.

Blake, G.R. 1965. Bulk density. p. 374-377. In: Methods of Soil Analysis, Part I. C.A. Black, ed. Amer. Soc. Agron. Inc. Madison, Wisconsin.

Branson, Farrel, Gerald Gifford, Kenneth Renard, Richard Hadley. 1981. Rangeland Hydrology. 2nd ed. Kendall/ Hunt Pub. Co. Dubuque, Iowa.

Dortignac, E.J. 1951. Design and operation of the Rocky Mountain infiltrometer. USDA Forest Service, Rocky Mt. Forest and Range Exp. Sta. Pap. 5.

Gifford, Gerald. 1981. Watershed responses to grazing management. p. 147-159. In: Proc. Interior West Watershed Manage. Symp., April 8-10, 1980. David Baumgartner, ed. Washington State Univ., Cooperative Ext., Pullman.

Gifford, Gerald, and Richard Hawkins. 1978. Hydrologic impact of grazing on infiltration: a critical review. Water Resources Res. 14:305-313.

Haise, Howard, William Donnan, John Phelan, Lester Lawhan and Dell Shockley. 1956. The use of cylinder infiltrometers to determine the intake characteristics of irrigated soils. USDA Agr. Res. Serv. and S.C.S. ARS 41-7.

Moore, Elbert, Eric Janes, Floyd Kinsinger, Kenneth Pitney, and John Sainsbury. 1979. Livestock grazing management and water quality protection. U.S. Environmental Protection Agency, Region 10. EPA 910/9-79-67.

Morisawa, M. 1968. Streams, Their Dynamics and Morphology. McGrawHill Book Co., New York.

Skovlin, John, Robert Harris, Gerald Strickler, George Garrison. 1976. Effects of cattle grazing methods on ponderosa pine-bunchgrass range in the Pacific Northwest. USDA Forest Serv. Tech. Bull. 1531.

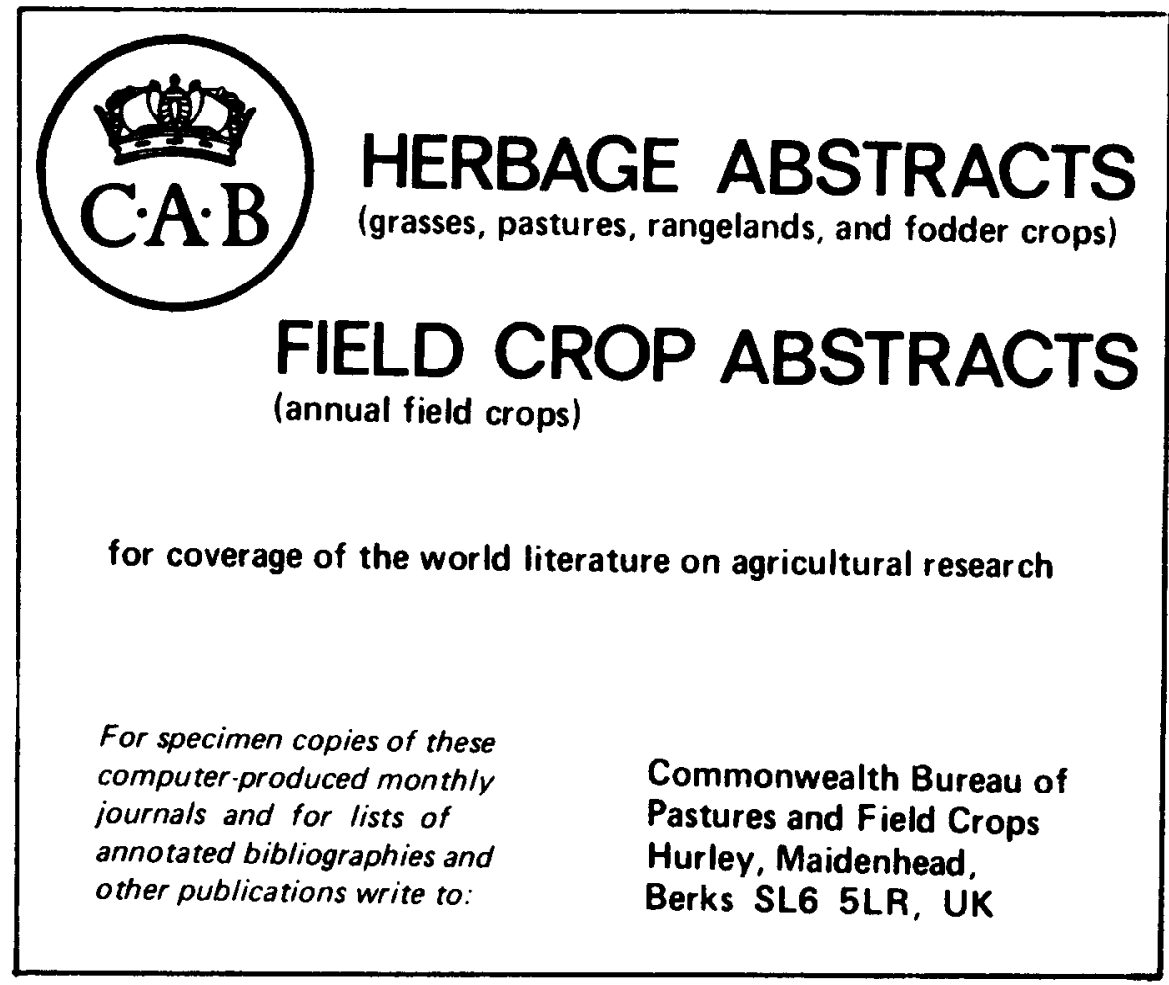

